Good mentors come in all shapes and sizes. Age, gender, and race are irrelevant. It is not so much who they are or what they do but the way that they do it. A mentor that's right for you may not suit someone else. And, what you need today could be different in the future. So, how will you recognise a good mentor?

First, think about the type of mentoring you want:

(1) Traditional mentoring: a person with experience in a particular field, or someone who has achieved what you want to achieve, shares their knowledge, introduces you to people or provides resources that will aid your progress.

(2) A role model: someone whose behaviors, attitude, and strategies you can emulate to achieve success.

(3) Developmental mentoring: someone who listens, questions, and enables you set goals, create plans, make decisions, and solve problems related to your career or professional growth.

(4) Reciprocal mentoring: a relationship where neither party is designated "mentor." Each is a confidante and resource to the other. You share goals and encourage personal accountability. You each serve as a sounding board for ideas and a reality check for plans.

(5) Group mentoring: the classic mastermind concept of tapping into collective wisdom and obtaining mutual support.

(6) Coaching: personalised training to develop specific skills and improve performance.

\section{Qualities of a mentor}

The abilities that most good mentors have in common are:

(1) Communication skills: listening, questioning, and the wise use of silence

(2) Being a sounding board for ideas and a reality check for plans

(3) Giving guidance without being directive

(4) Providing feedback, suggestions, and options

(5) Time and willingness to contribute

(6) Confidentiality, respecting personal privacy

\section{Finding a traditional mentor}

Traditional mentoring was depicted in "Horatio Hornblower" the fictional story of an English naval cadet whose innate ability was recognized and fostered by his captain. Both rose through the ranks. The patronage of the senior man and the loyal support of the younger one served them both. However, difficulties with this kind of mentoring may arise in an organisational context. Issues related to equity, power and dependence can have negative consequences. Potential mentors may be threatened by a younger person who may become a

\footnotetext{
Korean J Med Educ 2017 Mar; 29(1): 41-43.

https://doi.org/10.3946/kjme.2017.52

eISSN: $2005-7288$

(C) The Korean Society of Medical Education. All rights reserved.

This is an open-access article distributed under the terms of the Creative

Commons Attribution Non-Commercial License (http://creativecommons.org/ licenses/by-nc/3.0/), which permits unrestricted non-commercial use, distribution, and reproduction in any medium, provided the original work is properly cited.
} 
competitor or have the talent to rise above them.

To avoid the problems of traditional mentoring, you may seek a mentor who has retired, works in another organization or remote location, or a confident and generous person with altruistic motivation.

Sometime these mentors have registered their interest as part of a program. They may have been identified by the program coordinator or Human Resources staff in your organization, or they may be members of a professional association, industry body or service club. Traditional mentoring is prevalent in the arts. The Sydney Symphony, the NSW Writers Centre and the Australian Arts Council all provide mentoring programs to nurture new talent.

To find such a person for yourself, network. Use the principle of "six degrees of separation." Someone you know knows someone who knows someone, ask. Keep asking until a personal connection can be made. Ideally, the person introducing you to the mentor would lay the groundwork by recommending you.

Alternatively, research literature of the field of your interest to identify a likely candidate. A bit of effort should get you contact details and you can write, then follow up by phone. You may be pleasantly surprised that even quite high profile people may be amenable to the right approach.

\section{Role models}

You don't want to become a clone of anyone else. However, many people known to you, or observed from afar, have qualities that you can copy for your own advantage. No one is perfect and you may select the attributes that you want and ignore the less effective aspects.

Human beings have always learned this way. We observe and acquire behaviors and attitudes unconsciously from those around us, unless we make a deli- berate effort to resist. You can also consciously choose to pay attention to people you admire and reflect on their actions. Those you don't admire may also have much to teach you!

Using a role model involves identifying people that you believe operate in positive and effective ways, noticing what they do and how they do it and practicing it yourself.

Role models abound. If you can't access them near by, think about heroes both contemporary and historical. Read success stories, biographies and even fiction to identify people and characteristics you want to copy. Some books, such as Michael Gelb's: "How to think like Leonardo da Vinci," are specifically written for this purpose.

\section{Finding a mentor for development}

The mentoring process is more important than technical expertise in developmental mentoring. So you are looking for someone skilled in the use of facilitative communication-that is, someone who does more listening than talking! A person who asks thought provoking questions and can draw you out. These people usually have a reputation as "enablers." They develop their own staff and are known to help others. They know and use sound techniques for decision-making and problem- solving. They have life experience that allows them to be authoritative (not authoritarian) and they will challenge your thinking and help you evaluate alternative strategies for getting what you want. They will help you clarify your vision, set goals, and create practical plans to achieve them. They'll be around as you implement your plans so you can debrief and adjust your actions.

These people are easy to spot but they may be in high demand. They are good managers, well liked, and respected. If you don't see them in your organization, 
you may be moving in different circles. Again, you need to network and ask others who they'd recommend. Perhaps you have a previous manager or a colleague who has moved out of your area and fits the bill. Informal mentoring with people outside of the organization happens frequently and some workplaces are investigating reciprocal arrangements in structured mentoring programs.

\section{Reciprocal mentoring}

You probably have a friend or colleague already, with whom you share confidences. Reciprocal mentoring takes it a step further and formalises the nature of the relationship by mutual agreement. However, reciprocal mentoring is more than mutual reinforcement.

Friends can be too nice to you. Relatives, spouses, or lovers may lack the objectivity necessary for real mentoring. Mentoring can add stress to a relationship, so a professional colleague may be the best choice. You could find a peer at a conference or training course, through your membership in a professional association or a community group.

\section{Group mentoring}

Engaging a group takes the principle: "two heads are better than one" to the next level. Napoleon Hill, in the classic: "Think and grow rich," describes the "mastermind" technique used by people such as Henry Ford and Andrew Carnegie to achieve massive success. He likens the process to linking batteries to provide greater energy. When a group of individuals operate in harmony and share their brain power, the result is synergy - the whole is greater than the sum of the parts. In other words, the collective wisdom is available to each individual and shared ideas and information trigger additional possibilities that may never have been generated were each person working alone.

Some professional associations use the mastermind concept and can set you up a group. You may be able to join study or discussion groups, or book clubs to meet your needs. Otherwise you may have to find individuals with a common interest and create your own group.

\section{Coaching}

Coaching is different from mentoring (see Tip 2: Do I need a mentor or a coach?). If you need specific knowledge or skills to improve performance you can ask someone who has those skills to help you develop. The coach may demonstrate techniques, observe you as you practice and give corrective feedback. Your line manager or an experienced colleague may coach you or recommend someone. Frequently, senior managers and business people use professional coaches and "life coaches" are popular.

\section{Conclusion}

With the exception of some types of role modelling, each of the above involves you in a relationship. Any relationship requires self-acceptance and acceptance of others. So called "personality clashes" are really an inability or unwillingness to be flexible and communicate.

A good mentor will inevitably be different from youotherwise they'd have nothing to offer! While we find it easier to build rapport with those most similar to ourselves it is the differences that offer most leverage for self-development. 